\title{
The multifaceted effects induced by floods on the macroinvertebrate communities inhabiting a sinking cave stream
}

\author{
Octavian Pacioglu ${ }^{12^{*}}$, Nicoleta Ianovici ${ }^{1}$, Mărioara N. Filimon ${ }^{1}$, Adrian Sinitean ${ }^{1}$, Gabriel \\ Iacob $^{1}$, Henrietta Barabas ${ }^{1}$, Alexandru Pahomi ${ }^{1}$, Andrei Acs ${ }^{3}$, Hanelore Muntean ${ }^{4}$, and \\ Lucian Pârvulescu ${ }^{1}$
}

${ }^{1}$ Department of Biology-Chemistry, Faculty of Chemistry, Biology, Geography, West University of Timişoara, 16A Pestalozzi Street, 300115, Timişoara, Romania ${ }^{2}$ National Institute of Research and Development for Biological Sciences, Splaiul Independenței 296, 060031, Bucharest, Romania

${ }^{3}$ The Centre for Protected Areas and Sustainable Development, 4-6 1 Decembrie Square, 410048, Oradea, Romania

${ }^{4}$ Romanian Waters National Administration, 32 Mihai Viteazul Street, 300310, Timişoara, Romania

\begin{abstract}
First-order sinking cave streams experience considerable hydrological variability, including spates and periods of base-flow during dry seasons. Early-summer flooding on a first-order stream sinking in Ciur-Ponor Cave (Romania) represented a suitable opportunity to test the response of the macroinvertebrate community and of basal food resources quantity and diversity to such a disturbance event. The invertebrate community and basal resources (i.e., woody debris, leaves, fine particulate organic matter and epilithon) were collected from three sampling sites, before and after the flood. The sampling strategy followed an up-downstream gradient of both species diversity and quantity of allochtonous organic matter decrease as the stream flows through the cave. From each sampling site, ten replicates of both the benthic community and basal resources (detritus and epilithon) were taken. Outside the cave, the spate reduced the invertebrate community density, instant secondary production, complexity and stability (measured as eco-exergy and specific eco-exergy). The epigean section of the stream is populated mainly by taxa characteristic of karst headwaters prone to floods that usually recolonize the streambed rapidly from adjacent habitats. This effect was corroborated with a subsequent increase of both the mass of fine particulate organic matter and of invertebrate density within the cave, following the aftermath of the flood. In the river stretch situated close to the entrance $(100 \mathrm{~m})$, where the flood carried both live and dead organic matter, the stability index showed that the complexity of the community was not severely disturbed, despite the high influx of surface-dwelling taxa and temporary increase in species richness. Further downstream, in the third sampling site (400 m from entrance), all measured endpoints indicated a change in community stability, suggesting that local spates can act as rejuvenating drivers in shaping the invertebrate community structure and functioning.
\end{abstract}

Keywords: $\quad$ sinking cave streams, eco-exergy, floods, stygobites

Received 30 November 2018; Revised 18 June 2019; Accepted 19 June 2019

Citation: Pacioglu O., lanovici N., Filimon M.N., Sinitean A., lacob G., Barabas H., Pahomi A., Acs A., Muntean H. and Pârvulescu L., 2019. The multifaceted effects induced by floods on the macroinvertebrate communities inhabiting a sinking cave stream. International Journal of Speleology, 48 (2), 167-177. Tampa, FL (USA) ISSN 0392-6672

https://doi.org/10.5038/1827-806X.48.2.2239

\section{INTRODUCTION}

Cave streams lying near the surface are important ecotones connecting energy sources from the terrestrial environment to deep groundwater (Simon \& Benfield, 2001). One of the most critical questions related to understanding cave ecosystems was the identification of energy sources from the surface (Culver \& Pipan, 2009). Perhaps one of the most important types of energy input in caves is represented by sinking streams that comprise a heterotrophic endpoint in the continuum of lotic ecosystems (Simon et al., 2003). Some caves are connected to the surface by large openings that allow the entrance of detritus from the surface, which is presumably of higher quality compared to the low-energy subterranean realm (Schneider et al., 2010). Consequently, cave streams are characterised by shorter food webs and comprise fewer species compared to surface ecosystems (Gibert \& Deharveng, 2002; Venarsky et al., 2014). 
Wood, leaves and fine-grained detritus, from riparian vegetation enter cave streams and are transformed by abiotic and biotic processes while undergoing continual displacement downstream (Simon \& Benfield, 2001). After entering cave streams, detritus can be consumed, mineralized and transported downstream. However, most of organic matter input is linked to water flow which varies considerably across seasons (Ray, 2012). Sometimes, in smallorder streams, floods carry important quantities of detritus that represent an important pathway for organic matter entrance in such caves (Dickson \& Holsinger, 1982; Danielopol et al., 2000; Simon et al., 2007). However, the way these small pulses of organic matter, along with the floods, influences the structure and functionality of biological communities in such ecosystems remains a conundrum, because to our knowledge no study has tested such effects so far.

Understanding the structure and functioning of biological communities in sinking cave streams is therefore essential, as these may represent a significant input within the subterranean realm of living organic matter that reaches the deeper parts of caves through drift or scouring during floods (Gunn et al., 2000). Whilst many freshwater species contribute to the biodiversity of caves, such as meiofauna (Meleg et al., 2011, 2012; Mori \& Brancelj, 2013), the macroinvertebrates are among the most ubiquitous and widely used bioindicators for environmental disturbances, such as floods in karst streams (Meyer \& Meyer, 2000; Stubbington et al., 2009). Moreover, floods represent significant environmental drivers that support the colonisation of caves by ubiquitous macroinvertebrates and that may relatively short time periods become stygophiles (facultative cave-dwellers, i.e., Gammarus minus and Asellus aquaticus, see Hetrick \& Gooch, 1981; Protas et al., 2011). Therefore, the assessment of both structural characteristics and ecological processes of benthic macroinvertebrate assemblages are important to provide a better understanding of the way that floods can influence karst sinking stream ecosystem dynamics (Meyer \& Meyer, 2000; Stubbington et al., 2009).

Besides the classic diversity indices (i.e., Shannon index, equitability), thermodynamic oriented indices provide supplementary information on the self-organizing capacity of an ecosystem (Silow \& Mokry, 2010). These metrics were originally derived from physics, but proved to be equally suitable in ecology (Ludovisi et al., 2005). Among them, exergy is particularly useful to test such properties of an ecosystem (Linares et al., 2017). The exergy represents the useful energy contained within an ecosystem and is calculated as eco-exergy (EXG) and specific eco-exergy (SPEXG) (Jørgensen, 2007). Whilst EXG represents the ability of an ecosystem to use external energy (Li et al., 2016), the SPEXG is derived from the former and measures the complexity (Mollozzi et al., 2013), the stability and the development of the system under study (Linares et al., 2018). These variables alone, however, may not always fully characterise changes that occur in ecosystems functioning (Benke et al., 2001). Differences in community composition and basal resource quantity and diversity as induced by floods are frequently mirrored in other ecosystem properties, such as secondary production (Death, 2010). Secondary production assessment represents a suitable indicator for the overall success of a biological assemblage in response to floods (Dolbeth et al., 2012). However, its calculation requires labour-intensive data spanning at least one full year of sampling (Benke et al., 2001). Therefore, a methodological trade-off was developed to aid in its estimation, namely the Instant Secondary Production (ISP) (Edgar, 1990; Morin \& Dumont, 1994).

Our objective was to investigate the influence that floods have on the structure of the macroinvertebrate community and on the quantity and diversity of basal resources along an up-downstream gradient of a sinking cave stream. For that we tested the following hypotheses: (1) Floods will influence the macroinvertebrate community, leading to a decrease of their diversity, density, EXG, SPEXG and ISP along an up-downstream gradient after such a disturbance; (2) Floods will act as active vectors of energy input into the cave, leading to higher quantities of basal food resources carried downstream following such events.

\section{MATERIALS AND METHODS}

\section{Sampling design and study area}

We conducted this study in the late spring- summer $\left(25^{\text {th }}\right.$ of May and $15^{\text {th }}$ of July of 2018) in the Ciur-Ponor Cave (north-west of Romania, for geographic location see Ponta, 1994). The cave is over $20 \mathrm{~km}$ long and comprises a fishless first order sinking stream entering the cave that after approximately $400 \mathrm{~m}$ joins another stream with a fully subterranean course (Fig. 1). The sinking stream is therefore directly connected with the surface and receives allochtonous woody debris (WD), coarse particulate organic matter (CPOM, mostly leaves) and fine particulate organic matter (FPOM). Before reaching the cave, the watercourse is covered by a heavy canopy of deciduous trees, extending for a length of approximately three hundred meters. For this study we have surveyed three sampling sites that cover the range of organic matter diversity and quantity along an up-downstream gradient (Fig. 1). Therefore, the sampling site $\mathrm{S}_{1}$, situated at the surface, before the river enters the cave, was fuelled by both photosynthesis and detritus from the canopy $\left(S_{1}\right.$ in Fig. 1). The second sampling site, $S_{2}$, was situated at approximately $100 \mathrm{~m}$ after the cave's entrance and covers an area where significant traces of detritus are visible (WD, CPOM and FPOM) on the riverbed, but without photosynthesis input $\left(\mathrm{S}_{2}\right.$ in Fig. 1). The third sampling site, $\mathrm{S}_{3}$, was situated after approximately $400 \mathrm{~m}$ downstream from the cave entrance, before the confluence with its tributary with a full subterranean course and does not present visible traces of WD and CPOM, but with FPOM $\left(\mathrm{S}_{3}\right.$ in Fig. 1$)$. The stream macroinvertebrate community at sampling site $\mathrm{S}_{3}$ comprises only two species, a stygobiont (obligate cave dweller) and a stygophile: Niphargus bihorensis and a mixture of pigmented and depigmented varieties of Gammarus balcanicus (see Annex). The latter species 

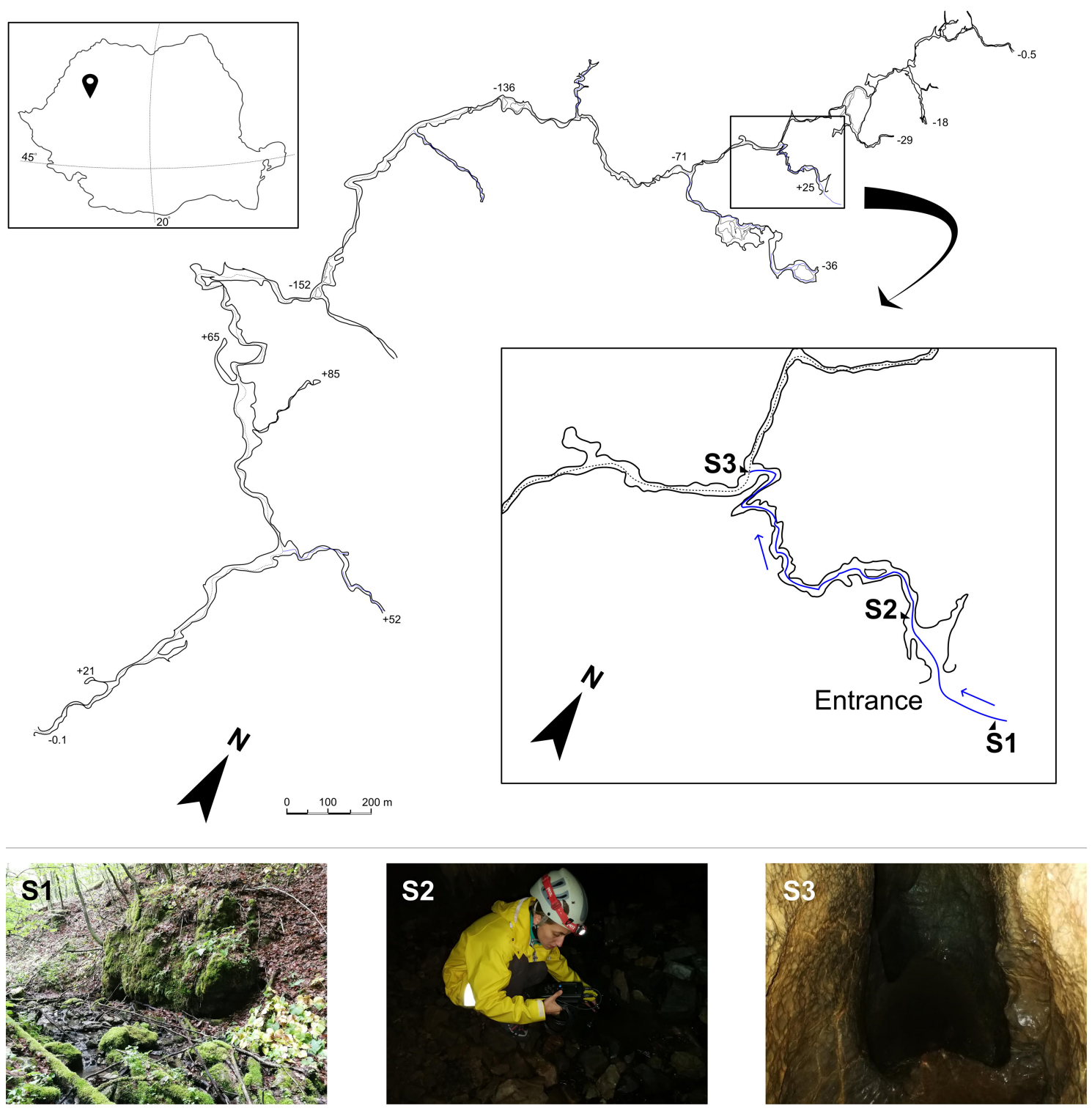

Fig. 1. The location of Ciur-Ponor Cave in Romania and its map to scale. Highlighted (not at scale) is the surveyed cave sector, with the sampling sites $S_{1}, S_{2}$, and $S_{3}$ (continuous line) and its confluence with the main subterranean water course (dashed lines). Pictures represent (from left to right) sites $S_{1}, S_{2}$, and $S_{3}$ during the first sampling campaign. The arrow represents the direction the river flows through the cave.

is equally found in sampling site $\mathrm{S}_{2}$, along with a limited number of other surface dwelling species (but co-dominant with the stygophile caddisfly Wormaldia occipitalis), whereas outside the cave, in sampling site $\mathrm{S}_{1}$, it represents the dominant species in the benthic community (see Annex).

The standing stock of epilithon, WD, CPOM, FPOM, and macroinvertebrates was estimated from samples collected in May and July 2018 (representing periods of low-base flow and following the flood, see below). We quantified the macroinvertebrate density (number $/ \mathrm{m}^{2}$ ) in samples collected with a Surber sampler $\left(0.106 \mathrm{~m}^{2}\right.$; mesh aperture $\left.250 \mu \mathrm{m}\right)$ from 10 sample-units taken on each date and distributed in a stratified-random design over $100 \mathrm{~m}$ of river from all three sampling sites. The samples were preserved in the field in $4 \%$ formalin, transported to the laboratory, where they were subsequently sorted for macroinvertebrates, which were identified to the lowest possible taxonomic level (usually species or genus, except Oligochaeta and Nematoda, see Annex). An eyepiece graticule was used to measure linear dimensions of each individual to the nearest $0.1 \mathrm{~mm}$ was used (dissecting microscope Olympus SZ61 type). The dry body mass was estimated from published length-mass regressions (Smock, 1980; Meyer, 1989; Burgherr \& Meyer, 1997; Benke et al., 1999; Tod \& Schmid-Araya, 2009). The EXG and SPEXG were calculated according to Jørgensen et al. (2010) and the ISP following Morin \& Dumont (1994). The remaining material from the Surber samples was passed through 2 stacked sieves (1-mm and $250 \mu \mathrm{m}$-mesh aperture) and following processing was used to determine the WD (particles $>1 \mathrm{~cm}$ ), CPOM (particles $1 \mathrm{~mm}$ $1 \mathrm{~cm}$ ) and FPOM (particles $>250 \mu \mathrm{m}$ but $<1 \mathrm{~mm}$ ) fractions per unit area $\left(\mathrm{m}^{2}\right)$. To quantify ash-free dry mass, the material was dried at $85^{\circ} \mathrm{C}$ to constant mass and subsequently combusted at $500^{\circ} \mathrm{C}$. On both sampling occasions, 10 stones were randomly selected from the streambed and the epilithic biofilm removed from a $20 \mathrm{~cm}^{2}$ area (delineated by a template) of the upper surface with a toothbrush. The samples were filtered through preweighed filters (Whatman $\mathrm{GF} / \mathrm{C}$ ), treated similarly as the detritus above and the ash-free dry mass of epilithon per unit area was estimated. 


\section{Hydrologic conditions}

Representative data for thelocal hydrologic conditions were recorded from a nearby gauging station (Vadu Crişului, $9 \mathrm{~km}$ from the cave entrance, for details of the location see Moldovan et al., 2012). The flow of the River Crișul Repede reflects the hydrologic variability across seasons from this cave (Moldovan et al., 2012). Daily averages were used for the interpretation of the flow regime (Fig. 2). The spring of 2018 was characterised by a severe drought, mainly in April (data not showed), that continued all the way through May, reflected in a daily mean discharge of $15 \mathrm{~m}^{3} / \mathrm{s}$ (Fig. 2). Therefore, the first sampling campaign $\left(25^{\text {th }}\right.$ of May) was considered as representative for base-flow conditions in the cave (Fig. 2). However, the month of June was characterised by heavy rainfall, mainly during the first half of the month, which increased the mean daily discharge of the river to $31.2 \mathrm{~m}^{3} / \mathrm{s}$ (Fig. 2). In the time period covering the end of June-beginning of July, the rainfall stopped and the mean discharge dropped to a daily mean of $20.4 \mathrm{~m}^{3} / \mathrm{s}$ (Fig. 2). A timeperiod of two weeks after the rainfalls stopped was considered appropriate to allow the invertebrate community to recover (Meyer \& Meyer, 2000); the second sampling campaign was carried on the $15^{\text {th }}$ of July 2018 (Fig. 2).

\section{Data analysis}

The macroinvertebrate community was analysed using NMDS ordination to visualise differences in community composition along the up-downstream gradient and potential differences in its structure induced by flood. Two-way PERMANOVA tests (1000 permutations), based on Euclidean distance, were employed to test if the benthic communities significantly differed among sampling sites and before and after the flood event. Subsequently, SIMPER analysis was used to identify which taxa were responsible for any differences induced by disturbance for each sampling site. Two-way PERMANOVA tests were employed to test for differences in WD, CPOM, FPOM, epilithon, and invertebrate's density, species richness, EXG, SPEXG and ISP among sampling sites and before and after the flood. All parameters were compared for each sampling site before and after the flood with post-hoc Mann-Whitney pairwise tests with Bonferroni corrections. All analyses were undertaken in PAST software, version 2.01.

\section{RESULTS}

Two-way PERMANOVA indicated significant differences in the structure of the invertebrate communities among sampling sites and following

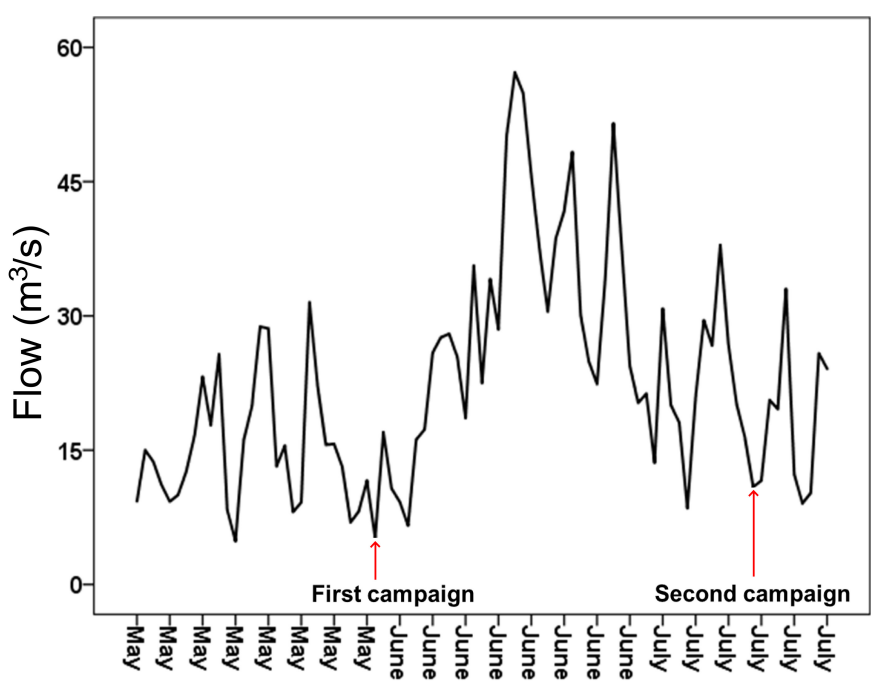

Fig. 2. The water flow of the River Crișul Repede $\left(\mathrm{m}^{3} / \mathrm{s}\right)$ registered at the gauging station Vadu Crișului, measured as daily averages, covering the time period of the survey (May-July 2018) and with indication of both sampling campaigns, representative for base-flow conditions and following the aftermath of the flood, respectively.

the aftermath of the flood (Table 1). The NMDS ordination (Stress value 0.018) suggested two main clusters, as follows: the invertebrate community from sampling sites $\mathrm{S}_{1}$ and $\mathrm{S}_{2}$ following the flood, showed a more similar community compared to a second cluster comprising sampling site $\mathrm{S}_{2}$ before the flood and $\mathrm{S}_{3}$ (Fig. 3). The SIMPER analysis indicated that sampling site $S_{1}$, situated outside the cave, registered a significant drop in $G$. balcanicus density $160 \%$ dissimilarity, Table 2), followed by chironomids and glossosomatid caddisflies, but to a much lesser degree (dissimilarity $<10 \%$, Table 2). G. balcanicus was responsible for the differences observed before and after the flood with the second sampling site, but to a smaller degree compared to surface (24\% dissimilarity, Table 2) and was followed by a drop in the density of the co-dominant species, W. occipitalis, compared to base-flow conditions (13.2\% dissimilarity, Table 2). However, these two species were not entirely responsible for the differences induced by the flood event (Table 1), since other surface-dwelling taxa (stygoxene, comprising mainly mayflies, caddisflies larvae and Oligochaeta) were present in this site at higher densities compared to base-flow conditions (dissimilarity $>10 \%$, Table 2). The SIMPER analysis revealed that the density of amphipods $G$. balcanicus and $N$. bihorensis increased following the flood event at sampling site $\mathrm{S}_{3}$ (Annex, Tables 2 and 3).

In addition to community structure, the invertebrate density and EXG showed significantly higher values following the flood event inside the cave (Table 3). The general patterns were significant decreases of both parameters outside the cave following the flood event,

Table 1. F values for two-way PERMANOVA tests for species richness, woody debris (WD), coarse particulate organic matter (CPOM), fine particulate organic matter (FPOM), epilithon, invertebrates' density, eco-exergy (EXG), specific eco-exergy (SPEXG) and instant secondary production (ISP) across sampling sites and before and after the flood.

\begin{tabular}{|c|c|c|c|c|c|c|c|c|c|}
\hline Factor & $\begin{array}{l}\text { Species } \\
\text { richness }\end{array}$ & WD & CPOM & FPOM & Epilithon & $\begin{array}{c}\text { Invertebrate } \\
\text { density }\end{array}$ & EXG & SPEXG & ISP \\
\hline Flood & $6.73^{* * *}$ & 0.29 & 0.09 & $2.08^{*}$ & 0.8 & $1.64^{*}$ & $4.88^{* * *}$ & $1.51^{*}$ & $2.72^{* *}$ \\
\hline Site & $4.44^{* * *}$ & $4.6^{* * *}$ & $1.91^{* *}$ & $3.32 * * *$ & $0.46^{*}$ & $2.3^{* *}$ & $4.86 * * *$ & $1.1^{* *}$ & $4.48^{* * *}$ \\
\hline Flood x Site & $0.9 * *$ & 0.4 & 0.3 & 0.29 & 0.41 & 0.07 & 1.86 & 0.53 & 0.51 \\
\hline
\end{tabular}




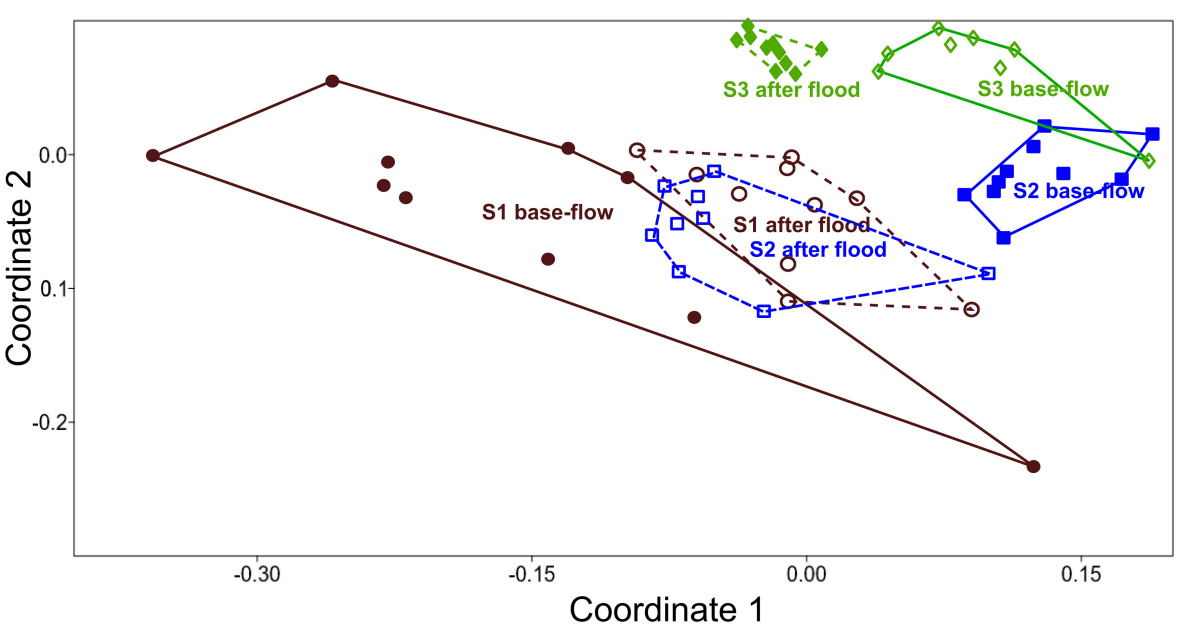

Fig. 3. NMDS ordination of the benthic macroinvertebrate community in all three sampling sites, before and after the flood.

Table 2. Results of SIMPER analysis for taxa dissimilarity per each sampling sites before and after the flood.

\begin{tabular}{|l|c|c|c|c|c|c|c|c|}
\hline Site & $\begin{array}{c}\text { Gammarus } \\
\text { balcanicus }\end{array}$ & Orthocladiinae & Glossosoma sp. & $\begin{array}{c}\text { W. } \\
\text { occipitalis }\end{array}$ & $\begin{array}{c}\text { Paraleptophlebia } \\
\text { submarginata }\end{array}$ & $\begin{array}{c}\text { Ecdyonurus } \\
\text { torrentis }\end{array}$ & $\begin{array}{c}\text { Oligochaeta } \\
\text { toiphargus } \\
\text { bihorensis }\end{array}$ \\
\hline $\mathrm{S}_{1}$ & $59.9 \%$ & $7.7 \%$ & $5.01 \%$ & - & - & - & - & - \\
\hline $\mathrm{S}_{2}$ & $24 \%$ & - & $11.3 \%$ & $13.2 \%$ & $12.5 \%$ & $11.3 \%$ & $7.5 \%$ & - \\
\hline $\mathrm{S}_{3}$ & $73.6 \%$ & - & - & - & - & - & - & $23.8 \%$ \\
\hline
\end{tabular}

but an increase further downstream (Fig. 4A-4B, Table 3). However, SPEXG at sampling site $\mathrm{S}_{2}$ did not differ significantly before and after the flood event (Fig. 4C, Table 3). The ISP registered a significant decrease in the river stretch situated outside the cave following the spate, whereas inside the cave the opposite pattern was observed, with significantly higher values in the aftermath of the flood (Fig. 4D, Table 3).

The detrital fractions did not differ significantly across sampling sites following the flood, except FPOM mass, which increased significantly inside the cave (Fig. 5A-C, Tables 1 and 3). Nevertheless, these fractions differed significantly among sampling sites, with the highest masses recorded for WD, CPOM and FPOM outside the cave and decreasing along an up-downstream gradient (Fig. 5A-C, Table 1). The epilithon mass was lower at sampling site $S_{3}$ compared to the upstream sites, but was not affected by the flood event (Fig. 5D, Tables 1 and 3).

\section{DISCUSSION}

Disturbance is one of the critical driving forces in shaping the structure of macroinvertebrate communities in streams and rivers and has been well studied (Resh et al., 1988; Death, 2002; 2010; Lake, 2000), although its role in subterranean systems is poorly understood (Gunn et al., 2000). Although there were previous studies that focused on flow permanence and the influence of spates in karst streams, they referred only to those with an epigean course (Meyer \& Meyer, 2000; Stubbington et al., 2009, 2012) or inferred indirectly the effects of such disturbances on subterranean ecosystems (Gunn et al., 2000; Rađa \& Puljas, 2010; Dumnicka et al., 2015).

Both tested hypotheses from this survey were at least partially confirmed. The diversity of invertebrates increased in sampling site $\mathrm{S}_{2}$ following the flood (Fig. 3 , see Annex), whereas outside the cave a massive reduction of the community's density, EXG, SPEXG and ISP was observed (Fig. 4A-4D). The response of invertebrates outside the cave was intuitive with the first hypothesis, suggesting that the flood was strong enough to transport a wide range of taxa downstream (Fig. 3). However, the response of the macroinvertebrate community was not as linear as expected, since in the third sampling site, situated $400 \mathrm{~m}$ from the entrance, registered a significantly higher density following the flood event, exactly the opposite pattern observed outside the cave (Fig. 4A). In addition to density, the invertebrate community comprising mainly the amphipods G. balcanicus and $N$. bihorensis showed a significant increase of EXG, SPEXG and ISP following the flood (Fig. 4B-4D). Given that the biology of both amphipods is rather different (the former species is a stygophile, whilst the latter is a stygobite), their apparent response induced by

Table 3. Scores for post-hoc Mann-Whitney pairwise tests with Bonferroni correction for each sampling site, before and after the flood, for species richness, woody debris (WD), coarse particulate organic matter (CPOM), fine particulate organic matter (FPOM), epilithon, invertebrate density, eco-exergy (EXG), specific eco-exergy (SPEXG) and instant secondary production (ISP).

\begin{tabular}{|c|c|c|c|c|c|c|c|c|c|}
\hline Sites & $\begin{array}{l}\text { Species } \\
\text { richness }\end{array}$ & WD & CPOM & FPOM & Epilithon & Density & EXG & SPEXG & ISP \\
\hline $\mathrm{S}_{1}$ & -1.29 & -1.05 & -0.75 & -2.2 & -0.6 & $-2.76^{*}$ & $-3.78^{*}$ & $-2.6^{*}$ & $-3.25^{*}$ \\
\hline $\mathrm{S}_{2}$ & $-3.84^{*}$ & -1.74 & -1.2 & $-2.43^{*}$ & -0.8 & $-3.75^{*}$ & $-3.1^{*}$ & -2.26 & $-3.17^{*}$ \\
\hline $\mathrm{S}_{3}$ & 0.07 & -0.62 & -0.98 & $-2.57^{*}$ & -0.83 & $-3.78^{*}$ & $-2.87^{*}$ & $-3.47^{*}$ & $-3.9 *$ \\
\hline
\end{tabular}





Fig. 4. Mean $( \pm$ SE) of macroinvertebrate density $(A)$, eco-exergy $(B)$, specific eco-exergy $(C)$ and Instant Secondary Production (D) in all three sampling sites, before (grey bars) and after the flood (black bars).

Density is expressed as number of individuals $/ \mathrm{m}^{2}$ and ISP as $\mathrm{mg} / \mathrm{m}^{2} /$ day.

flow variability could have different explanations. The gammarids are known to be frequent dwellers both outside and within caves (Culver \& Pipan, 2009), with species like G. minus in USA (Culver et al., 1995) and G. pulex in UK (Knight et al., 2018), existing as permanent subterranean populations that colonise both actively (Turquin, 1973) and passively, via drift, these ecosystems (Carlini et al., 2009). The latter genus is known to respond positively to floods in caves and groundwater aquifers, increasing their density directly with flow reactivation (Barr, 1968; Gledhill, 1977; Gibert et al., 1981; Turquin \& Barthelemy, 1985; Mathieu \& Turquin, 1992). Given that the habitats of many niphargids are mostly located within the network of fissures within the limestone aquifers (Mathieu \& Turquin, 1992; Wood et al., 2008) and reaching the cave conduits occasionally, it is possible that floods acted as important drivers of their local density and instant secondary production.

The response of the invertebrate community in the second sampling site suggested that the scouring effect induced by spates was effective for a number of surface-dwelling taxa (stygoxene) $100 \mathrm{~m}$ downstream from the cave entrance (Fig. 3 and 4A). This sampling site registered a large number of mayfly and caddisfly larvae following the spate, along with some Oligochaeta (Annex). Similarly to sampling site $\mathrm{S}_{3}$, following the flood, an increase of the community's density, ISP and EXG was recorded (Fig. 4B and D). Nevertheless, the SPEXG in this sampling site was not significantly affected by the flood (Fig. 4C). The SPEXG expresses the overall degree of complexity and development of a biological system (Jørgensen, $2007 a, b)$. Its similar values before and after the spate suggest that overall, specific eco-exergy, or average organism complexity, has rapidly recovered in terms of information flux through the community (sensu
Patricio et al., 2006). In fact, SPEXG, after only two weeks following the flood, showed comparable values with base-flow conditions, suggesting therefore an analogous structural complexity. Thus, the system information appears to have recovered much faster than biomass (see below). A potential explanation for this may be that despite many stygoxene macroinvertebrates observed within caves not far from the entrance, their presence is usually considered accidental and the potential to establish permanent subterranean populations is slim (Sket, 2008; Trajano, 2012), because very often they comprise typical epigean insect larvae that are carried by floods or that use this habitat only for short periods of time (Sket, 1999; Manenti et al., 2013; Knight et al., 2018). The species that was mostly responsible for the observed difference in community change in density and secondary production after the spate was, the same as further downstream, G. balcanicus. Given that depigmented morphs of this species occurred infrequently during base-flow conditions (data not showed) and following the spate all individuals were pigmented, it is likely that this species, along with the others, was washed into the cave. Of particular interest was the high abundance of the caddisfly larvae $W$. occipitalis that apparently maintains a selfsustaining population in the sector. This species was found before in large numbers penetrating caves for long distances from the entrance (Sket, 1993; Gunn et al., 2000) and is considered a stygophile that lives and that reproduces underground (Sket, 2008). The fact that its density was reduced after the flood but was not found further downstream in sampling site $\mathrm{S}_{3}$, could suggest however a confounded effect of the spate with the life cycle of this species. During base-flow conditions this species represented the co-dominant taxa in the benthic community, with adults present in 



Fig. 5. Mean ( \pm SE) of woody debris (A), CPOM (B), FPOM (C) and epilithon (D), measured as ash-free dry mass $\left(\mathrm{g} / \mathrm{m}^{2}\right)$ in all three sampling sites, before (grey bars) and after the flood (black bars).

high numbers on the cave walls during both sampling campaigns (personal observations). Outside caves, the adults of this species were frequently caught every month of the year, except winter (Mackereth, 1960; Jones, 1969), leading to the conclusion that it is possible that this stygophile species was not directly affected by the flood.

The most visibly affected sector was the site situated outside the cave. It seems that the spate disturbed most of the invertebrates, significantly reducing their abundance and hence the entire community EXG, SPEXG and ISP (Fig. 4). Nevertheless, the taxonomic composition did not differ significantly between events (Fig. 3, Annex), suggesting that the studied stream is inhabited by taxa which are typical of flood-impacted sites (e.g., Suren \& Jowett, 2006). Karst streams were shown to contain such taxa, that allow a very rapid recovery of the benthic community following floods (Stubbington etal., 2009). The dominance of gammarids during base-flow conditions in karst streams, their decrease following the aftermath of floods and their rapid recovery had been attributed to their ability to recolonize streams from longitudinally connected surface waters or adjacent hyporheic habitats (Gunn et al., 2000). Other taxa, like the Oligochaeta, Pisidum sp., Baetis sp., Ecdyonurus sp., Simuliidae blackflies are likely to recover fast following the spate and are equally characteristic of flood-prone karstic streams (Gunn et al., 2000; Rader et al., 2008). Floods can create patchy environments that maintain habitat heterogeneity and thus the invertebrate diversity (Robinson \& Uehlinger, 2003; Lepori \& Hjerdt, 2006). All flood-prone streams studied by Death (1996) had a remarkably similar fauna dominated by Heptageniidae mayflies, Simuliidae, Chironomidae and Oligochaeta, taxa most able to recover relatively quickly from flood disturbances (Death, 2010).
Higher EXG values found within the cave following the flood can be explained by higher amounts of energy input available (Marchi et al., 2011), resulting in an increased use of resources to build more complex dissipative structure (Jørgensen, 2007a, b; Jørgensen et al., 2007), corresponding principally to biomass storage (growth form I - see Jørgensen et al., 2016). Similar findings to those observed in this survey were found in ecosystems where eutrophication occurred, resulting in more energy available to benthic assemblages and consequent increase in EXG (Marques et al., 1997; Molozzi et al., 2013). The wash-out effect for allochtonous FPOM, presumably of greater quality than those already existing in this cave-system (Schneider et al., 2010) had apparently a concurrent effect on community structure and complexity. The cave food-webs are known to contain significantly fewer species compared to surface streams (Venarsky et al., 2014) and a potential explanation for this phenomenon could be related to the quantity and quality of basal food sources (Simon et al., 2003; Schneider et al., 2010; Popović et al., 2019). However, inputs of CPOM and WD into cave streams are extremely heterogeneous across space because they are concentrated in areas that are directly connected to the surface by large openings (Simon \& Benfield, 2001). Moreover, the results of this survey confirmed previous findings, such as that CPOM and WD are usually transported over very short distances $\left(<20 \mathrm{~m}\right.$ year $\left.{ }^{-1}\right)$ from their entry points in small-order cave streams (Simon \& Benfield, 2001, 2002; Francois et al., 2016). In contrast, the FPOM fraction is intimately associated with microbes and represents a ubiquitous food source in caves for stygobites (Kinsey et al., 2007; Francois et al., 2016). Nevertheless, given that other types of energy inputs in cave environments are of low quality and 
infrequent (e.g. dissolved nutrients in percolation water), the transport via spates of allochtonous basal food sources (mainly FPOM) proved to be paramount for the long-term existence of metazoan life within the subterranean realm (Culver, 1981; Culver \& Pipan, 2009; Schneider et al., 2010; Venarsky et al., 2014).

\section{CONCLUSIONS}

Although cave streams have fewer species compared to surface ecosystems, they comprise a very dynamic community where spates may act as rejuvenating factors. Our results showed that basal resources (mainly FPOM) of allochotonous origin, along with the active wash-out of epigean invertebrates can help support reasonably complex invertebrate communities in cave streams and is directly supported by flow variations. Moreover, the intrusion of surface-dwelling taxa in the cave sector situated not far from the entrance has not affected the community' complexity (in a thermodynamic context, sensu Jørgensen, 2007b), despite offering it, besides fine grained detritus, pulses of living organic matter, important for the long-term co-existence of the stygophile species that form permanent populations in these habitats. The sector situated outside the cave is populated by taxa usually prone to floods, which recolonize the riverbed quickly, usually from habitats adjacent to the water course, such as the hyporheic zone. The surface benthic community is dominated by the amphipod Gammarus balcanicus that is equally dominant in other sectors of the cave, where it persists as permanent populations and where presumably it fulfils a very important role within local food-webs.

\section{ACKNOWLEDGMENTS}

We are grateful to the Romanian Waters National Administration, Crișuri Water branch, for providing us real-time measurements of flows collected at the gauging station Vadu Crișului. We are equally indebted to The Centre for Protected Areas and Sustainable Development, who provided us access and help during field work in the Ciur-Ponor Cave. We thank Vasile Giurgiu who gave us permission to use the cave map (Fig.1) and Adrian Blejdea for pictures of sampling sites (Fig. 1A, 1B and 1C). The research was funded by the National Core Program funded by the Romanian Ministry of Research and Innovation Program 25N19-270103, BIODIVERS2, PN-103.

\section{REFERENCES}

Barr T.C., 1968 - Cave ecology and the evolution of troglobites. In: Dobzhansky T., Hecht M.K. \& Steere W.C. (Eds.), Evolutionary biology, Springer, Boston, p. 35-102.

https://doi.org/10.1007/978-1-4684-8094-8 2

Benke A.C., Huryn A.D., Smock L.A. \& Wallace J.B., 1999 - Length-mass relationships for freshwater macroinvertebrates in North America with particular reference to the southeastern United States. Freshwater Science, 18: 308-343.

https://doi.org/10.2307/1468447
Benke A.C., Wallace J.B., Harrison J.W. \& Koebel J.W., 2001 - Food web quantification using secondary production analysis: predaceous invertebrates of the snag habitat in a subtropical river. Freshwater Biology, 46: 329-346.

https://doi.org/10.1046/j.1365-2427.2001.00680.x

Burgherr P. \& Meyer E.I., 1997 - Regression analysis of linear body dimensions vs. dry mass in stream macroinvertebrates. Fundamental and Applied Limnology, 139: 101-112.

Carlini D.B., Manning J., Sullivan P.G. \& Fong D.W., 2009 - Molecular genetic variation and population structure in morphologically differentiated cave and surface populations of the freshwater amphipod Gammarus minus. Molecular Ecology, 18: 1932-1945. https://doi.org/10.1111/j.1365-294X.2009.04161.x

Culver D.C., 1981 - Some implications of competition for cave stream communities. International Journal of Speleology, 11: 49-62.

https://doi.org/10.5038/1827-806X.11.1.6

Culver D.C., Kane T.C. \& Fong D.W., 1995 - Adaptation and natural selection in caves: the evolution of Gammarus minus. Harvard University Press, 223 p. https://doi.org/10.4159/harvard.9780674419070

Culver D.C. \& Pipan T., 2009 - The biology of caves and other subterranean habitats. Oxford University Press, Oxford, $272 \mathrm{p}$.

Danielopol D.L., Pospisil P. \& Rouch R., 2000 Biodiversity in groundwater: A large-scale view. Trends in Ecology and Evolution, 15: 223-224. https://doi.org/10.1016/S0169-5347(00)01868-1

Death R.G., 1996 - The effect of patch disturbance on stream invertebrate community structure: the influence of disturbance history. Oecologia, 108: 567-576. https://doi.org/10.1007/BF00333735

Death R.G., 2002 - Predicting invertebrate diversity from disturbance regimes in forest streams. Oikos, 97: 18-30. https://doi.org/10.1034/j.1600-0706.2002.970102.x

Death R.G., 2010 - Disturbance and riverine benthic communities: what has it contributed to general ecological theory?. River Research and Applications, 26: 15-25. https://doi.org/10.1002/rra.1302

Dickson G.W. \& Holsinger J.R., 1981 - Variation among populations of the troglobitic amphipod crustacean Crangonyx antennatus Packard (Crangonyctidae) living in different habitats, III: population dynamics and stability. International Journal of Speleology, 11: 33-48. https://doi.org/10.5038/1827-806X.11.1.5

Dolbeth M., Cusson M., Sousa R. \& Pardal M.A., 2012 Secondary production as a tool for better understanding of aquatic ecosystems. Canadian Journal of Fisheries and Aquatic Sciences, 69: 1230-1253.

https://doi.org/10.1139/f2012-050

Dumnicka E., Galas J., Karlikowska J. \& Sznober N., 2015 - Temporary co-existence of aquatic and terrestrial invertebrates in shallow periodically flooded and frozen cave. Biologia, 70: 1201-1209.

https://doi.org/10.1515/biolog-2015-0142

Edgar G.J., 1990 - The use of the size structure of benthic macrofaunal communities to estimate faunal biomass and secondary production. Journal of Experimental Marine Biolology and Ecology, 137: 195-214. https://doi.org/10.1016/0022-0981(90)90185-F

Francois C.M., Mermillod-Blondin F., Malard F., Fourel F., Lécuyer C., Douady C.J. \& Simon L., 2016 - Trophic ecology of groundwater species reveals specialization in a low-productivity environment. Functional Ecology, 30: 262-273.

https://doi.org/10.1111/1365-2435.12484 
Gibert J. \& Deharveng L., 2002 - Subterranean ecosystems: a truncated functional biodiversity. BioScience, 52: 473481. https://doi.org/10.1641/0006-3568(2002)052[0473: SEATFB]2.0.CO;2

Gibert J., Ginet R., Mathieu J. \& Reygrobellet J.L., 1981 - Structure et fonctionnement des écosystèmes du Haut-Rhône Français; IX: Analyse des peuplements de deux stations phréatiques alimentant des bras morts. International Journal of Speleology, 11: 141-158. https://doi.org/10.5038/1827-806X.11.1.14

Gledhill T., 1977 - Numerical fluctuations of four species of subterranean amphipods during a five year period. Crustaceana Supplement, 144-152.

Gunn J., Hardwick P. \& Wood P.J., 2000 - The invertebrate community of the Peak-Speedwell cave system, Derbyshire, England-pressures and considerations for conservation management. Aquatic Conservation: Marine and Freshwater Ecosystems, 10: 353-369. https://doi.org/10.1002/1099-0755(200009/10) 10:5\%3C353::AID-AQC413\%3E3.0.CO;2-S

Hetrick S.W. \& Gooch J.L., 1981 - Genetic differentiation in populations of the freshwater amphipod Gammarus minus Say in a karst area. International Journal of Speleology, 11: 7-13.

https://doi.org/10.5038/1827-806X.11.1.2

Jones N.V., 1969 - The emergence of Trichoptera from a small ground-fed stream in North Wales. Entomologist's Monthly Magazine, 105: 151-155.

Jørgensen S.E., Fath B., Bastianoni S., Marques J.C., Müller F., Nielsen S.N., Patten B.C., Tiezzi E. \& Ulanowicz R., 2007 - A new ecology. Systems Perspective. Elsevier, 275 p.

Jørgensen S.E., Ludovisi A. \& Nielsen S.N., 2010 - The free energy and information embodied in the amino acid chains of organisms. Ecological Modelling, 221: 2388-2392.

https://doi.org/10.1016/j.ecolmodel.2010.06.003

Jørgensen S.E., 2007a - Evolution and exergy. Ecological Modelling, 203: 490-494.

https://doi.org/10.1016/j.ecolmodel.2006.12.035

Jørgensen S.E., 2007b - An integrated ecosystem theory. Annals of the European Academy of Science, 20062007, 19-33.

Jørgensen S.E. \& Fath B.D., 2004 - Application of thermodynamic principles in ecology. Ecological Complexity, 1: 267-280.

https://doi.org/10.1016/j.ecocom.2004.07.001

Jørgensen S.E. \& Mejer H., 1977 - Ecological buffer capacity. Ecological Modelling, 3: 39-61.

https://doi.org/10.1016/0304-3800(77)90023-0

Jørgensen S.E., Marques J.C. \& Nielsen S.N., 2016 Integrated Environmental Management: A Transdisciplinary Approach. CRC Press, Taylor and Francis Group, Boca Raton, 369 p. https://doi.org/10.1201/b18740

Kinsey J., Cooney T.J. \& Simon K.S., 2007 - A comparison of the leaf shredding ability and influence on microbial films of surface and cave forms of Gammarus minus. Hydrobiologia, 589: 199-205.

https://doi.org/10.1007/s10750-007-0739-x

Knight L.R., Brancelj A., Edwards F. \& Maurice L., 2018 - The aquatic invertebrate fauna of the Ogof Draenen cave system in South Wales, UK. Cave and Karst Science, 45: 19-30.

Lake P.S., 2000 - Disturbance, patchiness, and diversity in streams. Freshwater Science, 19: 573-592.

https://doi.org/10.2307/1468118

Lepori F. \& Hjerdt N., 2006 - Disturbance and aquatic biodiversity: reconciling contrasting views. AIBS Bulletin, 56: 809-818.

https://doi.org/10.1641/0006-3568(2006)56[809: DAABRC]2.0.CO;2
Li D., Erickson R.A., Tang S., Zhang Y., Niu Z., Liu H. \& Yu H., 2016 - Structure and spatial patterns of macrobenthic community in Tai Lake, a large shallow lake, China. Ecological Indicators, 61: 179-187.

https://doi.org/10.1016/j.ecolind.2015.08.043

Linares M.S., Callisto M. \& Marques J.C., 2017 - Invasive bivalves increase benthic communities complexity in neotropical reservoirs. Ecological Indicators, 75: 279-285. https://doi.org/10.1016/j.ecolind.2016.12.046

Ludovisi A., Pandolfi P. \& Taticchi M., 2005 - The strategy of ecosystem development: specific dissipation as an indicator of ecosystem maturity. Journal of Theoretical Biology, 235: 33-43.

https://doi.org/10.1016/j.jtbi.2004.12.017

Mackereth M.J.C., 1960 - Notes on the Trichoptera of a stony stream. Proceedings of the Royal Entomological Society of London. Series A, General Entomology, 35: 17-23.

https://doi.org/10.1111/j.1365-3032.1960.tb00657.x

Manenti R., Siesa M. \& Ficetola G., 2013 - Odonata occurrence in caves: active or accidentals? A new case study. Journal of Caves and Karst Studies, 75: 205-209. https://doi.org/10.4311/2012LSC0281

Marchi M., Jørgensen S.E., Bécares E., Corsi I., Marchettini N. \& Bastianoni S., 2011 - Resistance and re-organization of an ecosystem in response to biological invasion: some hypotheses. Ecological Modelling, 222: 2992-3001.

https://doi.org/10.1016/j.ecolmodel.2011.04.017

Marques J.C., Pardal M.Â., Nielsen S.N. \& Jørgensen S.E., 1997 - Analysis of the properties of exergy and biodiversity along an estuarine gradient of eutrophication. Ecological Modelling, 102: 155-167. https://doi.org/10.1016/S0304-3800(97)00099-9

Mathieu J. \& Turquin M.J., 1992 - Biological processes at the population level II. Aquatic populations of Niphargus (stygobiont amphipod) case. In: Camacho A.I. (Ed.), The natural history of biospeleology, Academic Press, p. 232-265.

Meleg I.N., Moldovan O.T., Iepure S., Fiers F. \& Brad T., 2011 - Diversity patterns of fauna in dripping water of caves from Transylvania. Annales de LimnologieInternational Journal of Limnology, 47: 185-197. https://doi.org/10.1051/limn/2011014

Meleg I.N., Fiers F., Robu M. \& Moldovan O.T., 2012 Distribution patterns of subsurface copepods and the impact of environmental parameters. LimnologicaEcology and Management of Inland Waters, 42: 156-164. https://doi.org/10.1016/j.limno.2011.10.001

Meleg I.N., Zakšek V., Fišer C., Kelemen B.S. \& Moldovan O.T., 2013 - Can environment predict cryptic diversity? The case of Niphargus inhabiting Western Carpathian groundwater, PLoS One, 8: e76760. https://doi.org/10.1371/journal.pone.0076760

Meyer E., 1989 - The relationship between body length parameters and dry mass in running water invertebrates. Fundamental and Applied Limnology, 117: 191-203.

Meyer A. \& Meyer E.I., 2000 - Discharge regime and the effect of drying on macroinvertebrate communities in a temporary karst stream in East Westphalia (Germany). Aquatic Sciences, 62: 216-231.

https://doi.org/10.1007/PL00001333

Moldovan O.T., Meleg I.N. \& Perşoiu A., 2012 Habitat fragmentation and its effects on groundwater populations. Ecohydrology, 5: 445-452. https://doi.org/10.1002/eco.237

Molozzi J., Salas F., Callisto M. \& Marques J.C., 2013 - Thermodynamic oriented ecological indicators: application of eco-exergy and specific eco-exergy in 
capturing environmental changes between disturbed and non-disturbed tropical reservoirs. Ecological Indicators, 24: 543-551.

https://doi.org/10.1016/j.ecolind.2012.08.002

Mori N. \& Brancelj A., 2013 - Differences in aquatic microcrustacean assemblages between temporary and perennial springs of an alpine karstic aquifer. International Journal of Speleology, 42: 257-266. https://doi.org/10.5038/1827-806X.42.3.9

Morin A. \& Dumont P., 1994 - A simple model to estimate growth rate of lotic insect larvae and its value for estimating population and community production. Freshwater Science, 13: 357-367. https://doi.org/10.2307/1467365

Patrício J., Salas F., Pardal M.Â., Jørgensen S.E. \& Marques J.C., 2006 - Ecological indicators performance during a re-colonisation field experiment and its compliance with ecosystem theories. Ecological Indicators, 6: 43-57. https://doi.org/10.1016/j.ecolind.2005.08.016

Ponta G., 1994 - The Ciur Ponor-Toplița de Roşia Cave system. Journal of Westminster Speleology Group, 9: $56-61$.

Popović S., Nikolić N., Jovanović J., Predojević D., Trbojević I., Manić L. \& Subakov S.G., 2019 Cyanobacterial and algal abundance and biomass in cave biofilms and relation to environmental and biofilm parameters. International Journal of Speleology, 48: 4961. https://doi.org/10.5038/1827-806X.48.1.2224

Protas M.E., Trontelj P. \& Patel N.H., 2011 - Genetic basis of eye and pigment loss in the cave crustacean, Asellus aquaticus. Proceedings of the National Academy of Sciences, 108: 5702-5707.

https://doi.org/10.1073/pnas.1013850108

Rađa B. \& Puljas S., 2010 - Do Karst Rivers "deserve" their own biotic index? A ten years study on macrozoobenthos in Croatia. International Journal of Speleology, 39: 137-147. https://doi.org/10.5038/1827-806X.39.2.7

Rader R.B., Voelz N.J. \& Ward J.V., 2008 - Post-flood recovery of a macroinvertebrate community in a regulated river: Resilience of an anthropogenically altered ecosystem. Restoration Ecology, 16: 24-33. https://doi.org/10.1111/j.1526-100X.2007.00258.x

Ray J.A., 2012 - Sinking streams and losing streams. In: William W.B. \& Culver D.C. (Eds.), Encyclopedia of caves ( $2^{\text {nd }}$ Ed.), Academic Press, p. 707-712. https://doi.org/10.1016/B978-0-12-383832-2.00104-3

Resh V.H., Brown A.V., Covich A.P., Gurtz M.E., Li H.W., Minshall G.W., Reice S.R., Sheldon A.L., Wallace J.B. \& Wissmar R.C., 1988 - The role of disturbance in stream ecology. Freshwater Science, 7: 433-455. https://doi.org/10.2307/1467300

Robinson C.T. \& Uehlinger U., 2003 - Using artificial floods for restoring river integrity. Aquatic Sciences, 65: 181-182. https://doi.org/10.1007/s00027-003-0002-0

Schneider K., Kay A.D. \& Fagan W.F., 2010 - Adaptation to a limiting environment: the phosphorus content of terrestrial cave arthropods. Ecological Research, 25: 565-577. https://doi.org/10.1007/s11284-009-0686-2

Simon K.S. \& Benfield E.F., 2001 - Leaf and wood breakdown in cave streams. Freshwater Science, 20: 550-563. https://doi.org/10.2307/1468087

Simon K.S. \& Benfield E.F., 2002 - Ammonium retention and whole-stream metabolism in cave streams. Hydrobiologia, 482: 31-39.

https://doi.org/10.1023/A:1021257822591
Simon K.S., Benfield E.F. \& Macko S.A., 2003 - Food web structure and the role of epilithic biofilms in cave streams. Ecology, 84: 2395-2406.

https://doi.org/10.1890/02-334

Simon K.S., Pipan T. \& Culver D.C., 2007 - A conceptual model of the flow and distribution of organic carbon in caves. Journal of Cave and Karst Studies, 69: 279-284.

Silow E.A. \& Mokry A.V., 2010 - Exergy as a tool for ecosystem health assessment. Entropy, 12: 902-925. https://doi.org/10.3390/e12040902

Sket B., 1993 - Cave fauna and speleobiology in Slovenia. Nase Jame, 35 p.

Sket B., 1999 - The nature of biodiversity in hypogean waters and how it is endangered. Biodiversity and Conservation, 8: 1319-1338. https://doi.org/10.1023/A:1008916601121

Sket B., 2008 - Can we agree on an ecological classification of subterranean animals?. Journal of Natural History, 42: 1549-1563.

https://doi.org/10.1080/00222930801995762

Smock L.A., 1980 - Relationships between body size and biomass of aquatic insects. Freshwater Biology, 10: 375-383.

https://doi.org/10.1111/j.1365-2427.1980.tb01211.x

Stubbington R., Greenwood A.M., Wood P.J., Armitage P.D., Gunn J. \& Robertson A.L., 2009 - The response of perennial and temporary headwater stream invertebrate communities to hydrological extremes. Hydrobiologia, 630: 299-312.

https://doi.org/10.1007/s10750-009-9823-8

Stubbington R., Wood P.J. \& Reid I., 2011 - Spatial variability in the hyporheic zone refugium of temporary streams. Aquatic Sciences, 73: 499-511.

https://doi.org/10.1007/s00027-011-0203-x

Suren A.M. \& Jowett I.G., 2006 - Effects of floods versus low flows on invertebrates in a New Zealand gravel-bed river. Freshwater Biology, 51: 2207-2227. https://doi.org/10.1111/j.1365-2427.2006.01646.x

Turquin M.J. \& Barthelemy D., 1985 - The dynamics of a population of the troglobitic amphipod Niphargus virei Chevreux. Stygologia, 1: 109-117.

Tod S.P. \& Schmid-Araya J.M., 2009 - Meiofauna versus macrofauna: secondary production of invertebrates in a lowland chalk stream. Limnology and Oceanography, 54: 450-456.

https://doi.org/10.4319/10.2009.54.2.0450

Trajano E., 2012 - Ecological classification of subterranean organisms. In: William W.B. \& Culver D.C. (Eds.), Encyclopedia of caves (2 ${ }^{\text {nd }}$ Ed.), Academic Press, p. 275-277.

https://doi.org/10.1016/B978-0-12-383832-2.00035-9

Turquin M.J., 1973 - La colonisation de quelques grottes du Jura par Niphadobota alpina Bezzi (Dipt. Tipulidae). International Journal of Speleology, 5: 21-29. https://doi.org/10.5038/1827-806X.5.1.2

Venarsky M.P., Huntsman B.M., Huryn A.D., Benstead J.P. \& Kuhajda B.R., 2014 - Quantitative food web analysis supports the energy-limitation hypothesis in cave stream ecosystems. Oecologia, 176: 859-869. https://doi.org/10.1007/s00442-014-3042-3

Wood P.J., Gunn J. \& Rundle S.D., 2008 - Response of benthic cave invertebrates to organic pollution events. Aquatic Conservation: Marine and Freshwater Ecosystems, 18: 909-922.

https://doi.org/10.1002/aqc.933 
Annex. Mean ( $\pm \mathrm{SE}$ ) of species richness and density of invertebrates (individuals $/ \mathrm{m}^{2}$ ) in sites $\mathrm{S}_{1}, \mathrm{~S}_{2}$, and $\mathrm{S}_{3}$, during both sampling campaigns.

\begin{tabular}{|c|c|c|c|c|c|c|}
\hline Site & $S_{1}$ base-flow & $S_{1}$ after flood & $\mathbf{S}_{\mathbf{2}}$ base-flow & $S_{2}$ after flood & $S_{3}$ base-flow & $S_{3}$ after flood \\
\hline Species richness & $10.4 \pm 1.2$ & $8.2 \pm 2.5$ & $2.4 \pm 0.75$ & $7.3 \pm 1.7$ & $2.1 \pm 0.12$ & $2.1 \pm 0.11$ \\
\hline Oligochaeta & $18.87 \pm 13.8$ & $2.36 \pm 1.7$ & $1.89 \pm 1.3$ & $26.4 \pm 4.6$ & $3.14 \pm 2.2$ & $0.94 \pm 0.9$ \\
\hline Pisidium sp. (Bivalvia) & $11.8 \pm 6.8$ & 0 & 0 & 0 & 0 & 0 \\
\hline $\begin{array}{l}\text { Niphargus bihorensis } \\
\text { (Amphipoda) }\end{array}$ & 0 & 0 & 0 & 0 & $45.07 \pm 7.3$ & $77.3 \pm 11.2$ \\
\hline $\begin{array}{l}\text { Gammarus balcanicus } \\
\text { (Amphipoda) }\end{array}$ & $\begin{array}{l}1,147.4 \pm \\
461.2 \\
\end{array}$ & $99.84 \pm 14.4$ & $43.6 \pm 2.9$ & $121.7 \pm 14.5$ & $55.5 \pm 7.1$ & $177.3 \pm 9.1$ \\
\hline $\begin{array}{l}\text { Cordulegaster bidentata } \\
\text { (Odonata) }\end{array}$ & $4.72 \pm 2.5$ & $3.1 \pm 1.3$ & 0 & $2.8 \pm 1.4$ & 0 & 0 \\
\hline $\begin{array}{l}\text { Ephemera vulgata } \\
\text { (Ephemeroptera) }\end{array}$ & $42.4 \pm 12.2$ & $10.2 \pm 5.7$ & 0 & $38.7 \pm 5.7$ & 0 & 0 \\
\hline Baetis rhodani & $4.72 \pm 3.5$ & $0.8 \pm 0.7$ & 0 & 0 & 0 & 0 \\
\hline $\begin{array}{l}\text { Ecdyonurus torrentis } \\
\text { (Ephemeroptera) }\end{array}$ & $25.9 \pm 14.3$ & $10.2 \pm 4.4$ & 0 & $37.7 \pm 6.3$ & 0 & 0 \\
\hline $\begin{array}{l}\text { Paraleptophlebia submarginata } \\
\text { (Ephemeroptera) }\end{array}$ & $38.9 \pm 17.4$ & $19.6 \pm 5$ & 0 & $38.6 \pm 6.3$ & 0 & 0 \\
\hline Leuctra sp. (Plecoptera) & $22.4 \pm 13.2$ & $13.3 \pm 3.4$ & 0 & 0 & 0 & 0 \\
\hline Elmis aenea (Coleoptera) & $30.6 \pm 14.6$ & $17.3 \pm 4.3$ & 0 & $16 \pm 8.4$ & 0 & 0 \\
\hline Glossosoma sp. (Trichoptera) & $61.3 \pm 23$ & $16.5 \pm 5.4$ & 0 & $16.9 \pm 6.7$ & 0 & 0 \\
\hline $\begin{array}{l}\text { Micropterna lateralis } \\
\text { (Trichoptera) }\end{array}$ & $2.3 \pm 2.1$ & $4.72 \pm 4.1$ & 0 & 0 & 0 & 0 \\
\hline $\begin{array}{l}\text { Wormaldia occipitalis } \\
\text { (Trichoptera) }\end{array}$ & $20.4 \pm 5.5$ & $11.8 \pm 10.5$ & $51.8 \pm 9.6$ & 0 & 0 & 0 \\
\hline $\begin{array}{l}\text { Hydropsyche fulvipes } \\
\text { (Trichoptera) }\end{array}$ & $5.9 \pm 5.1$ & $1.57 \pm 1.1$ & 0 & 0 & 0 & 0 \\
\hline $\begin{array}{l}\text { Sericostoma personatum } \\
\text { (Trichoptera) }\end{array}$ & $1.18 \pm 1.1$ & $0.8 \pm 0.6$ & 0 & 0 & 0 & 0 \\
\hline Orthocladiinae (Diptera) & $89.6 \pm 27.5$ & $27.5 \pm 5.5$ & $7.5 \pm 3.4$ & $21.7 \pm 10.5$ & 0 & 0 \\
\hline Ptychoptera (Diptera) & $7.08 \pm 4.5$ & $0.79 \pm 0.3$ & 0 & $0.94 \pm 0.7$ & 0 & 0 \\
\hline Ceratopogonidae (Diptera) & $2.3 \pm 1.5$ & 0 & 0 & 0 & 0 & 0 \\
\hline Tipula sp. (Tipulidae) & $3.5 \pm 2.4$ & $0.79 \pm 0.3$ & 0 & 0 & 0 & 0 \\
\hline Simuliidae (Diptera) & $10.6 \pm 4.5$ & $5.5 \pm 1.4$ & 0 & 0 & 0 & 0 \\
\hline Antocha vitripennis (Tipulidae) & $2.3 \pm 2.1$ & $2.3 \pm 2.2$ & 0 & 0 & 0 & 0 \\
\hline Scleroprocta sp. (Tipulidae) & 0 & $0.79 \pm 0.6$ & 0 & 0 & 0 & 0 \\
\hline
\end{tabular}

